\title{
MICROBIAL WATER QUALITY ASSESSMENT OF PACKAGED DRINKING WATER OF PRE-SCHOOL CHILDREN IN SOME PARTS OF ACCRA
}

\author{
R. A. Banu, E. D. O. Ansa*, M. O. Akrong, G. A. Ansa And M. Bello, \\ (E.D.O.A., R. A. B., M. O. A. \& M. B.: CSIR Water Research Institute, P. O. Box AH 38, \\ Accra, Ghana; G. A. A.: University Hospital, Legon, P. O. Box LG 79, Legon-Accra, Ghana). \\ *Corresponding author's email: edoansa@yahoo.com
}

\begin{abstract}
Episodes of Cholera outbreaks are still common in most developing countries and children usually are at the greatest risk. This study assessed the importance of diarrhoea-related illnesses among children five years of age or less at the University Hospital, Legon and the importance of packaged water handling in the contamination of drinking water of pre-school children. Diarrhea-related diseases (DRD) accounted for $6.3 \%$ of cases involving children five years and below reporting at the University Hospital, Legon during the period of the study. Generally, greater number of cases (DRD) were reported among males (6.9\%) than among females (5.6\%). High counts above recommended levels of either Total Heterotrophic Bacteria, Pseudomonas or Total Coliforms were observed in $88 \%$ of the water samples tested. Inadequate cleaning of water bottles and in some instances the use of inappropriate water bottles (reusing PET mineral water containers) contributed to the poor quality of the drinking water of the preschool children. A greater part of the contamination of the drinking water occurred at home and not at the schools. Parents therefore need to be targeted with water, sanitation and hygiene related health education.
\end{abstract}

\section{Introduction}

Diarrhea-related diseases are still prevalent in Africa and children usually are at the greatest risk. In 2013, 6.3 million children died within five years of living and 0.578 million of these deaths $(9.2 \%)$ was attributed to diarrhea-related diseases. In 2015, of the 5.3 million children who died in their first five years of their lives, 1.2 million deaths were attributed to diarrhea-related diseases, despite the $50 \%$ global reduction in diarrhea-related cases (WHO, 2014; UNICEF, 2016). It had been estimated that children below the age of three years gets three episodes of diarrhea each year (WHO, 2005).
In developing countries where diarrhea-related diseases are mostly prevalent, the causes of these risks are not difficult to find. In Ghana, open drainage and lack of waste management systems are major drivers of malaria (the leading cause of death for children under age five) as well as diarrhea-related diseases (UNICEF, 2015), causing thousands of Ghanaian children to die each year from diarrhea-related diseases. Poor handling of food and drinking water of children may result in the spread of diarrhea-related diseases and the role of care givers is significant. Infectious diseases amongst children who have out-of-home child care are known to be twoto three times greater than children not in home care (NHS Highland, 2006). Pri- 
vate schools in Ghana provide food to pupils during lunch times at least. In public schools, the Government of Ghana through the School Feeding Program, provide meals to about 1.69 million children nationwide, representing a coverage of $37.4 \%$ (MOGCSP, 2016). The risk of food contamination among school children is well documented in literature (Osei-Tutu \& Anto, 2016; Malm et al., 2015; Monney et al., 2013; Newman, 2005) and $88 \%$ of cases of diarrhea-related diseases worldwide are attributable to unsafe water, inadequate sanitation or insufficient hygiene.

Typically, children under five years in crèches go to school with their own packaged drinking water in reusable bottles, refilled polyethylene terephthalate (PET) bottles, commercially packaged bottled water or sachet water from water vendors or from school canteens etc. The average capacity of reusable bottle used by pupil range from $500 \mathrm{ml}$ to $700 \mathrm{ml}$ and this suggests that packaged water sent to school may not be sufficient for the whole day and may need to be refilled. On the other hand, other researchers have suggested that some children may drink less when at school compared to when at home (Rugg-Gunn et al.,1987).

The objective of this study is to assess the importance of diarrhea-related diseases among children five years of age or less in the West Ayawaso-Wuogon, Madina and Adenta areas as reported by cases in the University Hospital, Legon and to identify the importance of packaged water handling in homes and schools in the contamination of drinking water of preschool children who are five years old or less. The study therefore assessed the status of packaged drinking water of pre-schoolers in terms of Escherichia coli, Pseudomonas and Coliform contamination both in the morning and in the afternoon.

\section{Experimental}

\section{Hospital data acquisition}

To assess the importance of diarrhea-related illness in the study area, secondary data was obtained from the records of the University Hospital, Legon, Ghana of patients reporting at the Out Patients Department (OPD) between January-March 2014. Records of 857 patients who are five years of age or below, reporting at the OPD of the hospital was screened for those who were positive for diarrhea-related illness. From the hospital records, the residential location of patients was categorized as Legon, Madina, Achimota, Adenta and Haatso, all of which were within $15 \mathrm{~km}$ distance of the University Hospital, Legon.

Cases diagnosed as positive for diarrhea-related illness in the consulting room register are those with three or more loose stools within 24 hours occurring in the previous five days who were with or without clinical symptoms. Stool samples were examined for physical characteristics such as presence of blood and mucus. A portion of the faecal sample emulsified in physiological saline were examined under the microscope to detect the presence of parasites. With the aid of various bacteriological cultural agar, stool samples were cultured for the isolation of enteric bacteria within two hours of sample collection using methods outline in Dutta et al. (2013).

\section{Sampling of drinking water from preschools}

A list of all pre-schools in the study area was obtained from the Ghana Education Service. 10 pre-schools were selected by simple randomized design using a table of random numbers (Altman, 1991). Five out of the 10 pre-schools randomly selected from these localities agreed to participate in study. 
Morning (7:30-8:30am) and afternoon (1:30$2: 30 \mathrm{pm})$ drinking water samples as well as swab samples of bottle heads of preschool children (aged 2-5) in the selected schools were obtained for bacteriological analysis. Twenty milliliters of water samples were obtained and for morning samples, care was taken to ensure samples were obtained from only children who have not drunk any of their water. The inner portions of bottle heads were swabbed aseptically into tubes containing $5 \mathrm{ml}$ sterile distilled water. Afternoon samples were obtained from the water bottles of the same pupils sampled in the morning. Water samples were immediately kept on ice at $4^{\circ} \mathrm{C}$ and transported to the laboratory for analysis. All analyses were carried out immediately on reaching the laboratory. The laboratory is within 25 minutes' drive of the sampling locations.

\section{Bacteriological analysis of water samples}

Suspension obtained from swabs and water samples were vortexed for $30 \mathrm{sec}$ and inoculated for the culture of Total coliform (TC), faecal coliform (FC), Escherichia coli (E. coli) and Pseudomonas aeruginosa (PA) using the membrane filtration technique. Filtration was done using cellulose nitrate membrane filters of pore size $0.45 \mu \mathrm{m}$ and diameter $47 \mathrm{~mm}$ (Millipore Ltd, UK). Determination of TC and E. coli were done by placing filters on chromogenic HiCrome coliform agar (Fluka) while FC was cultured by inoculating on M-FC Agar (Fluka). Analysis for Pseudomonas aeruginosa was done similarly using cetrimide agar (Fluka). Plates were incubated at $37 \pm 0.50 \mathrm{C}$ for 24 hours. The analysis for Total heterotrophic bacteria (THB) was done using the spread plate technique on nutrient agar (Fluka). One (1) milliliter each of water and swabbed samples were pipetted into labeled sterile petri plates containing nutrient agar. Plates were incubated at $37 \pm 0.5^{\circ} \mathrm{C}$ for 48 hours. Plating of samples was performed in triplicates and all media were prepared according to manufacturer's instructions. After incubation visible colonies of bacteria were counted with the aid of a colony counter and results expressed in colony forming units (cfu) per $100 \mathrm{ml}$ of analyzed samples. All analysis carried out followed methods outlined in the Standard Methods for the Examination of Water and Wastewater (APHA, 2012) and results obtained were compared to the Ghana Drinking Water Standards GS175-1 (GSA, 2013).

\section{Questionnaire administration}

100 questionnaires were administered to parents out of which 83 was retrieved. Responses to structured questionnaires were obtained from parents through the heads of the preschools. Parents were asked to indicate their preference with respect to how they pack water for their children or whether they pay the school to supply potable water for the children. Parents were also asked to indicate if any, their means of packing drinking water for their children, whether they sterilize the drinking water containers used by their children and how it is sterilized.

\section{Ethical clearance}

Ethical clearance to conduct this tests on the water of pre-school children was obtained from the institutional committee after consent of the Schools had been obtained. Written permission to access hospital data was also sought and obtained. Researchers did not come into contact with patients nor did they handle any specimen from any patient. 
Statistical Analysis

Hospital records of children five years or less were categorized into their various locations or suburbs of residence as well as their sex. These variables were compared using the Chi square test of Epi Info 7.2 software (Center for Disease Control, Atlanta, Georgia). Counts of bacteria in drinking water of morning and afternoon samples from the various schools were compared using paired sample t-test of SPSS 20.0 (Statistical Package for Social Scientists). Responses of parents on their preferences for their wards use of potable water at school, means of packaging potable water and the means of sterilization if any were compared using one-way ANOVA of SPSS 20.0.

\section{Results}

Occurrence of diarrhea-related diseases among children Hospital records showed that for the 857 children five years old or less reported at the OPD during the period of the study. Diarrhea-related diseases accounted for $6.3 \%$ of cases involving children five years and below reporting at the University Hospital during the period of the study. Generally, greater number of cases were reported among males (6.9\%) than among females (5.6\%) (Chi square test, $\mathrm{P}$ $<0.05$ ). Reported cases from Achimota were the highest (7.6\%) while Adenta showed the lowest (5.2\%) (Table 1). At Madina, Achimota and Haatso males had significantly higher cases than females in the same localities respectively (Chi square test, $\mathrm{P}<0.05$ ). There were more cases among females than males in the suburbs of Legon and Adenta however (Chi square test, $\mathrm{P}<0.05$ ).

TABLE 1

Diarrhea-related cases among children 5 years or less in some suburbs of Accra as observed from hospital records.

\begin{tabular}{|c|c|c|c|c|c|c|c|c|c|}
\hline \multirow[t]{2}{*}{ Localities } & \multicolumn{3}{|l|}{ Males } & \multicolumn{3}{|c|}{ Females } & \multirow{2}{*}{$\begin{array}{l}\text { Total } \\
\text { No. } \\
\text { Exam. }\end{array}$} & \multirow{2}{*}{$\begin{array}{l}\text { Total } \\
\text { No. } \\
+ \text { ve }\end{array}$} & \multirow[t]{2}{*}{$(\%)$} \\
\hline & $\begin{array}{l}\text { No. } \\
\text { Exam. }\end{array}$ & $\begin{array}{l}\text { No. } \\
+ \text { ve }\end{array}$ & $(\%)$ & $\begin{array}{l}\text { No. } \\
\text { Exam. }\end{array}$ & $\begin{array}{l}\text { No. } \\
+ \text { ve }\end{array}$ & $(\%)$ & & & \\
\hline Legon & 164 & 9 & 5.5 & 123 & 9 & 7.3 & 287 & 18 & 6.3 \\
\hline Madina & 95 & 9 & 9.5 & 96 & 4 & 4.2 & 191 & 13 & 6.8 \\
\hline Achimota & 70 & 8 & 11.4 & 61 & 2 & 3.3 & 131 & 10 & 7.6 \\
\hline Adenta & 99 & 4 & 4.0 & 56 & 4 & 7.1 & 155 & 8 & 5.2 \\
\hline Haatso & 35 & 2 & 5.7 & 58 & 3 & 5.2 & 93 & 5 & 5.4 \\
\hline Total & 463 & 32 & 6.9 & 394 & 22 & 5.6 & 857 & 54 & 6.3 \\
\hline
\end{tabular}

Bacteriological quality of drinking water of the pre-school children 50 water samples (comprising 25 mornings and 25 afternoon samples) analyzed, showed only six (6) water samples satisfying the criteria for potability (Table 2). Of the six (6) potable samples, only one sample was taken in the afternoon. Drinking water is deemed potable when all indicator parameters analyzed fall within permissible limits. The Ghana drinking water standards requires that potable water or samples have zero detectable counts of TC, EC and PA per $100 \mathrm{ml}$ of water analyzed while THB counts must remain below $500 \mathrm{cfu} / 100 \mathrm{ml}$. 
TABLE 2

Distribution of both morning and afternoon swabbed and water samples that were potable (-) and those not potable $(+)$ from five preschools in Accra. Potability is based on guidelines of Ghana Standards (GS-175, 2013).

\begin{tabular}{|c|c|c|c|c|}
\hline \multirow[t]{2}{*}{ School } & \multicolumn{2}{|c|}{ Morning } & \multicolumn{2}{|c|}{ Afternoon } \\
\hline & Water Sample & Swab Sample & Water Sample & Swab Sample \\
\hline \multicolumn{5}{|l|}{ School 1} \\
\hline 1 & - & - & + & + \\
\hline 2 & + & + & + & + \\
\hline 3 & + & + & + & + \\
\hline 4 & - & - & + & + \\
\hline 5 & + & + & + & + \\
\hline \multicolumn{5}{|l|}{ School 2} \\
\hline 6 & + & + & + & + \\
\hline 7 & + & + & + & + \\
\hline 8 & + & + & + & + \\
\hline 9 & + & + & + & + \\
\hline 10 & + & + & + & + \\
\hline \multicolumn{5}{|l|}{ School 3} \\
\hline 11 & + & + & + & + \\
\hline 12 & + & + & + & + \\
\hline 13 & + & + & + & + \\
\hline 14 & + & + & + & + \\
\hline 15 & + & + & + & + \\
\hline \multicolumn{5}{|l|}{ School 4} \\
\hline 16 & + & + & + & + \\
\hline 17 & - & - & + & + \\
\hline 18 & + & + & + & + \\
\hline 19 & + & + & + & \\
\hline 20 & + & + & + & + \\
\hline \multicolumn{5}{|l|}{ School 5} \\
\hline 21 & + & + & + & - \\
\hline 22 & - & + & - & + \\
\hline 23 & + & + & + & + \\
\hline 24 & + & - & + & - \\
\hline 25 & - & + & + & + \\
\hline Total Not Potable & 20 & 21 & 24 & 23 \\
\hline Potable & 5 & 4 & 1 & 2 \\
\hline
\end{tabular}

Generally, no significant differences were observed in bacterial counts of morning and afternoon water samples for Total Coliforms (Table 3), E. coli (Table 4), Pseudomonas aeruginosa (Table 5) and Total Heterotrophic bacteria (Table 6). A similar observation was made for swab samples taken in the morning and afternoon. School 1 showed significantly higher counts in Total Coliforms in the morning than in the afternoon but Total Coliform counts in swab samples from that same school were significantly higher in the afternoon than in the morning $(\mathrm{P}<0.05)$. E. coli counts were observed only at schools 5 and 2, with school 2 showing contamination only in water samples in the afternoon. All the water and swab samples of all the five schools showed high counts in Pseudomonas aeruginosa, with very high counts $(26,340 \pm 6,914 \mathrm{cfu} / 100 \mathrm{ml})$ in afternoon water sample of School 1, suggesting significant contamination. At school 2, significantly higher counts of total heterotrophic bacteria were observed in the afternoon water samples compared to the morning samples $(\mathrm{P}<0.05)$. 
TABLE 3

Mean Total Coliform (TC) concentrations \pm standard deviation in water samples and cover of water bottles (swab sample) in cfu/100 ml.

\begin{tabular}{llllll}
\hline Location & \multirow{2}{*}{$\begin{array}{l}\text { Number of } \\
\text { samples }\end{array}$} & \multicolumn{2}{c}{ Water Samples } & \multicolumn{2}{c}{ Swab samples } \\
\cline { 3 - 6 } & & Morning & Afternoon & Morning & Afternoon \\
\hline School 1 & 5 & $3162 \pm 1194$ & $874 \pm 224$ & $46 \pm 25$ & $388 \pm 58$ \\
School 2 & 5 & $2139 \pm 1581$ & $7298 \pm 2256$ & $804 \pm 91$ & $681 \pm 161$ \\
School 3 & 5 & $935 \pm 311$ & $1223 \pm 715$ & $476 \pm 267$ & $103 \pm 37$ \\
School 4 & 5 & $1680 \pm 821$ & $1034 \pm 477$ & $277 \pm 91$ & $809 \pm 109$ \\
School 5 & 5 & $2418 \pm 1357$ & $1782 \pm 734$ & $472 \pm 252$ & $195 \pm 132$ \\
\hline
\end{tabular}

TABLE 4

Escherichia coli (EC) concentrations in water samples and cover of water bottles (swab sample) in cfu/100 ml.

\begin{tabular}{|c|c|c|c|c|c|}
\hline \multirow[t]{2}{*}{ Location } & \multirow{2}{*}{$\begin{array}{l}\text { Number of } \\
\text { samples }\end{array}$} & \multicolumn{2}{|c|}{ Water Samples } & \multicolumn{2}{|c|}{ Swab samples } \\
\hline & & Morning & Afternoon & Morning & Afternoon \\
\hline School 1 & 5 & 0 & 0 & 0 & 0 \\
\hline School 2 & 5 & 0 & $63 \pm 47$ & 0 & 0 \\
\hline School 3 & 5 & 0 & 0 & 0 & 0 \\
\hline School 4 & 5 & 0 & 0 & 0 & 0 \\
\hline School 5 & 5 & $243 \pm 77$ & $266 \pm 68$ & $34 \pm 22$ & $57 \pm 33$ \\
\hline
\end{tabular}

TABLE 5

Pseudomonas aerugenosa (PA) concentrations in water samples and cover of water bottles (swab sample) in cfu/100 ml.

\begin{tabular}{llllll}
\hline Location & $\begin{array}{l}\text { Number of } \\
\text { samples }\end{array}$ & $\begin{array}{l}\text { Water Samples } \\
\text { Morning }\end{array}$ & Afternoon & $\begin{array}{l}\text { Swab samples } \\
\text { Morning }\end{array}$ & Afternoon \\
\hline School 1 & 5 & $5208 \pm 2628$ & $26340 \pm 6914$ & $3943 \pm 1641$ & $1668 \pm 1280$ \\
School 2 & 5 & $11514 \pm 1127$ & $16114 \pm 8367$ & $509 \pm 104$ & $353 \pm 58$ \\
School 3 & 5 & $3000 \pm 2053$ & $1152 \pm 476$ & $1574 \pm 383$ & $153 \pm 76$ \\
School 4 & 5 & $143 \pm 23$ & $188 \pm 94$ & $70 \pm 29$ & $103 \pm 54$ \\
School 5 & 5 & $693 \pm 271$ & $1024 \pm 353$ & $167 \pm 128$ & $192 \pm 69$ \\
\hline
\end{tabular}

TABLE 6

Total Heterotrophic Bacteria (THB) concentrations in water samples and cover of water bottles (swab sample) in cfu/100 ml.

\begin{tabular}{llllll}
\hline location & $\begin{array}{l}\text { Number of } \\
\text { samples }\end{array}$ & \multicolumn{2}{l}{ Water Samples } & \multicolumn{2}{l}{ Swab samples } \\
\cline { 3 - 6 } & 5 & $2353 \pm 1276$ & $3233 \pm 1828$ & $168 \pm 122$ & $180 \pm 106$ \\
\hline School 1 & 5 & $1698 \pm 1449$ & $3427 \pm 1632$ & $100 \pm 56$ & $112 \pm 82$ \\
School 2 & 5 & $1022 \pm 353$ & $1899 \pm 1437$ & $110 \pm 58$ & $137 \pm 85$ \\
School 3 & 5 & $1777 \pm 480$ & $1375 \pm 603$ & $77 \pm 67$ & $84 \pm 31$ \\
School 4 & 5 & $1779 \pm 763$ & $3140 \pm 455$ & $98 \pm 21$ & $68 \pm 31$ \\
School 5 & 5 & & & & \\
\hline
\end{tabular}




\section{Responses to questionnaires}

Eighty-three percent (83\%) of the 100 questionnaires administered were retrieved from the five (5) preschools. The survey of parents showed that only $12 \%$ of parents preferred the school providing drinking water for the pre-school children during school hours (Fig. 1). Majority of the parents (77\%), preferred packing their wards drinking water from home (Fig. 1a). Additionally, of the $77 \%$ parents who provided for their wards drinking water from home, $68 \%$ sterilized their water while $11 \%$ did not (Figure 1c). Forty-three percent of parents (43\%) used water bottles, $27 \%$ purchased factory packaged bottled water while $15 \%$ used PET mineral water bottles (Fig. 1b). Means of cleaning water containers included washing with soap and brush (48\%), washing in warm water $(23 \%)$, while others use other methods $(5 \%)$.
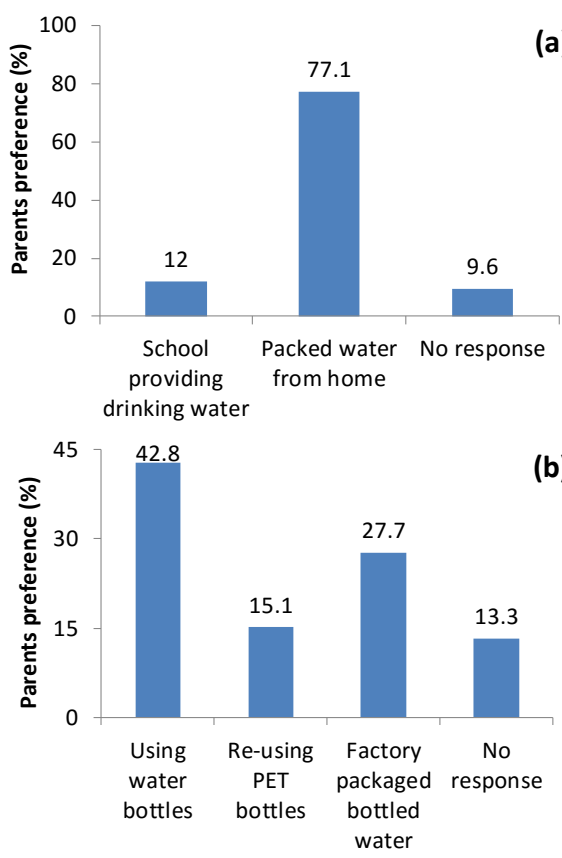

(a)

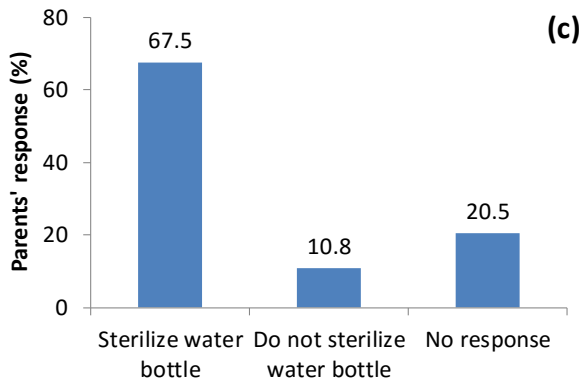

(b)

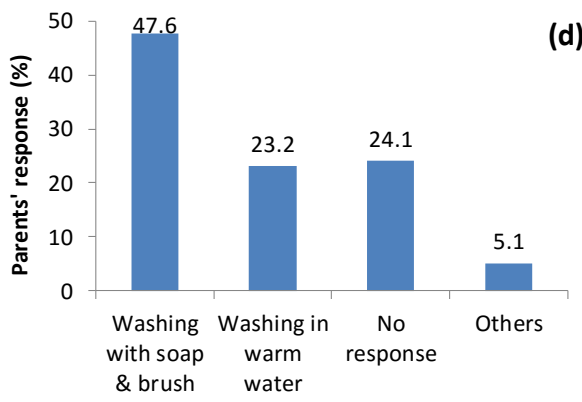

(c)

(d)

Fig. 1: Drinking water preferences of parents for their wards (a), types of containers used by parents for storing their children's drinking water (b), attitude of parents to sterilization of water bottles (c) and parents current water bottle sterilization practices $(\mathrm{d})$.

\section{Discussion}

Occurrence of diarrhea-related diseases among children . The occurrence of 54 positive cases $(6.3 \%)$ of diarrhea-related diseases from January to March of children five years and below as indicated by hospital records shows that diarrhea-related diseases is still a public health challenge in Ghana. The highest number of positive cases $(7.6 \%)$ came from Achimota while the lowest number of positive cases were recorded for residents coming from Adenta. The socio-economic status of a locality may influence the occurrence of the disease, with affluent areas expected to have less cases 
of the disease and vice versa. Understandably, poorer areas may have little sanitary infrastructure and less hygienic conditions for drinking water or food preparation (Motarjemi et al., 1993). Personal hygiene of individuals is also likely to improve with better standard of living. This may explain the lower number of positive cases coming from Adenta as opposed to Achimota. Adenta is a more affluent locality than Achimota. Hospital records showed that males (463 patients) had significantly more positive cases $(6.9 \%)$ than females $(5.6 \%)$ although Legon and Adenta showed a contrary trend (Table 3). Studies by Tawiah (2004) at the Princess Marie Louis Children's Hospital in Ghana observed more female children having cases of diarrhea-related illness than male children. This they attributed to the presence of more female children in the community. Hospital visits among male children is known to be higher than among female children (Parashar, 1999; Boccolini, 2012) and this observation is consistent with the findings of this study (Table 3 ). This may explain the higher overall percentage of positive cases of diarrhea-related illness among male children observed in this study.

Bacteriological quality of swabbed and drinking water samples

Generally, no significant differences $(\mathrm{P}<$ 0.05 ) were observed in bacterial counts of morning and afternoon water samples for Total Coliforms (Table 3), E. coli (Table 4), Pseudomonas aeruginosa (Table 5) and Total Heterotrophic bacteria (Table 6). A similar observation was made for swab samples taken in the morning and afternoon (Tables 3, 4, 5 and 6). Bacteria counts of swab samples (Total Coliforms, Pseudomonas aeruginosa and Total Heterotrophic bacteria Table 3, 4, 5 and 6) were also high and well above the recommended GSA (2013) levels. This was

unexpected as swabbed samples tend to be lower in count due to low recovery of bacteria by this technique (Eissa \& Mahmoud, 2012).

The Ghana drinking water standards requires that potable water must have zero detectable counts of TC, EC and PA per $100 \mathrm{ml}$ of water analyzed while THB counts must remain below $500 \mathrm{cfu} / 100 \mathrm{ml}$. Thus samples contaminated by only one bacteriological parameter would still not be adjudged as potable. Fifty (50) water samples were analyzed (for both morning and afternoon samples), and out of this, only six (6) satisfied the criteria for potability (Table 2). The presence of coliforms and THB above recommended levels is indicative of inadequate treatment of the water or contamination. The presence of PA can result in illness in persons with compromised immune system while presence of EC is indicative of faecal contamination of drinking water. Drinking water or food contaminated with faecal matter can result in the spread of diarrhea-related diseases. School 5 (Table 4) showed contamination with faecal matter for both swab and water samples, both in the morning and afternoon based on EC count observed.

Contamination of drinking water bottles of the pre-school children is obviously due to poor handling of drinking water package as well as poor personal hygiene. School 2 (Table 4) showed contamination of drinking water with faecal matter in the afternoon but not in the morning suggesting that contamination occurred at school as a result of inadequate hygienic practices.

Sixty-eight percent $(68 \%)$ of parents who use water bottle or used PET bottles to package their wards drinking water claimed they sterilize the water (Fig. 1c).However, $82 \%$ of the drinking water and swabbed samples were contaminated (Table 2), suggesting that their method of sterilization is not effective. Methods of 
sterilization used by parents included washing with soap and brush (48\% of parents), washing in warm water ( $23 \%$ of parents) and others $(5 \%)$. It was observed during the sampling period that some of the water bottles had sophisticated bottle heads with several levels of crevices that can make cleaning difficult. This may contribute to the ineffectiveness of the cleaning methods. WHO (2011) and (2015a) recommends the use of water heated to rolling boil point for rinsing after washing with brush and detergent. Stainless steel water bottles should also be preferred to plastic reusable ones as it is easier to clean.

\section{Conclusion}

Diarrhea-related diseases accounted for $6.3 \%$ of cases involving children five years and below reporting at the University Hospital during the period of the study. Generally, greater number of cases were reported among males (6.9\%) than among females (5.6\%). Reported cases from Achimota were the highest (7.6\%) while Adenta showed the lowest (5.2\%). This figures suggests that diarrhea-related diseases is still important in the West Ayawaso, Wuogon, Madina, Adenta and nearby municipalities. High counts above recommended levels of either Total Heterotrophic Bacteria, Pseudomonas or Total Coliforms were observed in $88 \%$ of the water samples tested. Inadequate cleaning of water bottles and in some instances the use of inappropriate water bottles (reusing PET mineral water containers) contributed in the poor quality of the drinking water of the preschool children. A greater part of the contamination of the drinking water occur at home and not at the schools. One school however showed contamination of $\mathrm{E}$. coli only in the afternoon suggesting that contamination of the drinking water occurred at the school.

\section{References}

Altman, D. G. (1991) Randomisation. BMJ 302, 1481 -1482 .

APHA (2012) Standard Methods for the Examination of Water and Wastewater, 22ndEdition. American Public Health Association, NY, USA.

Boccolini, C. S., Boccolini, P. D. M., De Carvalho, M. L. \& De Oliveira, M. I. (2012) Exclusive breastfeeding and diarrhea hospitilization patterns between 1999 and 2008 in between 1999 and 2008 in Brazilian capitals. Cien Saude Colet 17 (7), 1857 - 1863.

Dutta, S., Guin, S., Ghosh, S., Pazhani, G. P., Rajendran, K., Bhattacharya, M. K., Takeda, Y., Nair, G. B. \& Ramamurthy, T. (2013) Trends in the prevalence of diarrheagenic escherichia coli among hospitalized diarrheal patients in Kolkata, India. PLoS One 8 (2), 56068.

Eissa, M. E. \& Mahmoud, A. M. (2012) A Novel Improved Bioburden Recovery Method Using Swabbing Technique. International Journal of Microbiological Research 3 (3), 208 - 2015.

GsA (2013)Water Quality - Specification for drinking water GS 175-1:2013, Ghana Standards Authority, Accra.

Malm, K., Nyarko, K., Yawson, A., Gogo, B., LawSON, A., \& AfAri, E. (2015) Foodborne illness among school children in Ga east, Accra. Ghana Medical Journal, 49 (2), 72. https://doi. org/10.4314/gmj.v49i2.2

MOGCSP (2016). https://mogcsp.makeduconsult.com/ department-of-children/Accessed May 30th, 2018.

Monney, I., Agyei, D., \& Owusu, W. (2013) Hygienic Practices among Food Vendors in Educational Institutions in Ghana: The Case of Konongo. Foods 2, 282 - 294.https://doi.org/doi:10.3390/ foods 2030282 
Motarjemi, Y., Käferstein, F., Moy, G. \& Quevedo, F. (1993) Contaminated weaning food: a major risk factor for diarrhoea and associated malnutrition. Bulletin of the World Health Organization 71 (1), 79 - 92.

Newman, M. J. (2005) Food Safety: Take life easy; eat, drink and be merry. Luke 12: 19b. Ghana Medical Journal 39 (2), 44.

Nhs Highland (2006) Infection control guide for the pre-school setting. (www. nhsland.co.nhs.uk, Accessed March 17th, 2016).

Osei-Tutu, B. \& Anto, F. (2016) Trends of reported foodborne diseases at the Ridge Hospital, Accra, Ghana: a retrospective review of routine data from 2009-2013.BMC Infectious Diseases 16, $139-148$.

Panchalingam, S., Antonio, M., Hossain, A., MandoMANdo, I., Ochieng, B., Oundo, J., ... James, P. (2012) Diagnostic microbiologic methods in the GEMS-1 case/control study. Clinical Infectious Diseases 55, S294 - S302.

Parashar, U. D., Chung, M. C., Holman, R. C., RyDer, R.w., Hadler, L. J., Glass, R. I., (1999) Use of state Hospital Discharge Data to Assess the Morbidity from Rotavirus Diarrhea and to Monitor the impact of a Rotavirus Immunization Program: A Pilot Study in Connecticut 104 (3), 489 - 494. www.Pediatics.aappublications. org/content $/ 104 / 3 / 489$. Short.

Rugg-Gunn, A.J.,Hackett, A. F., Appleton, D. R., EAstoe, J. E., Dowthwaite, L., \& Wright, W. G. (1987). The water intake of 405 Northumbrian adolescents aged 12-14 years. British Bental Journal 162, 335 - 340.

Unicef (2015) Unicef Annual Report 2015. https:// www.unicef.org/about/annualreport/ files/Pakistan_2015_COAR.pdf, Accessed May 30th, 2018).
UNICEF (2016) One is too many: Ending child deaths from pneumonia and diarrhoea. ISBN: 97892-806-4859-1. 74 pp (https://www.unicef.org/ publications/index 93020.html, Accessed May 30th, 2018).

Who (2005) The Treatment of diarrhoea: a manual for physicians and other senior health workers. WHO/FCH/CAH/05.1, World health Organisation. ISBN: 9241593180, pp44.

Wно (2011) Guidelines for drinking-water quality. 4th Edition. World Health Organization, Geneva, ISBN: 9789241548151 pp564 (www.who. int/water_sanitation_health/publications/2011/ dwp_guidelines/en/ Accessed May 30th, 2018).

Wно (2012) Manual for Integrated Foodborne Disease Surveillance in the Who African Region. World Health Organization Regional Office for Africa Brazzaville.

Wно (2014) Preventing diarrhoea through better water, sanitation and hygiene exposures and impacts in low and middle income countries. World Health Organization.ISBN: 9789241564823, 48pp (http://www.who.int/water sanitation health/diseases-risks/gbd poor water/en/ Accessed May 30th, 2018).

WHо(2015a) Boil water. WHO/WC/WSH/15.02(http:// www.who.int//water sanitation health/ publications/2011/dwq guidelines/en/ Accessed May 30th, 2018).

Wно (2015b) Ghana: WHO statistical profile. Country Statistics and Global Health Estimates by WHO and UN Partners. (http://who.int/gho/ mortality burden_disease/en/) Accessed May 30th, 2018).

Received 11 Jun 18; revised 14 Nov 18. 